\title{
Functionality analysis and natural ventilation of social housing in times of pandemic
}

\author{
Análise da funcionalidade e ventilação natural da habitação social em tempos de pandemia \\ Análisis de la funcionalidad y ventilación natural de las viviendas sociales en tiempos de pandemia
}

Received: 09/01/2021 | Reviewed: 09/08/2021 | Accept: 09/10/2021 | Published: 09/15/2021

\author{
Kátia Jocasta Ortiz Grings \\ ORCID: https://orcid.org/0000-0002-1315-4960 \\ Universidade do Vale do Rio do Sinos, Brazil \\ E-mail: katiajocasta@gmail.com \\ Valéria Costa de Oliveira \\ ORCID: https://orcid.org/0000-0002-7852-1362 \\ Universidade do Vale do Rio do Sinos, Brazil \\ E-mail: valeria.oliveira@ifro.edu.br \\ Francisco Roger Carneiro Ribeiro \\ ORCID: https://orcid.org/0000-0001-8790-3023 \\ Universidade Federal do Rio Grande do Sul, Brazil \\ E-mail: roger.ribeiro_@hotmail.com \\ Jayson Pereira Godinho \\ ORCID: https://orcid.org/0000-0003-2948-8639 \\ Universidade Federal do Paraná, Brazil \\ E-mail: jayson.godinho.eng@gmail.com
}

\begin{abstract}
In the context of the COVID-19 pandemic, inadequate spaces in terms of the dimensions of the environments and lack of flexibility for possible adjustments, not only accentuate health risks, but also interfere in the productivity of remote work and school performance. In this sense, social housing has an unsatisfactory performance in terms of functionality, mainly because they have small spaces and inadequate window frames to achieve satisfactory natural ventilation and reduce the contagion by coronavirus. The objective of this article is to analyze three single-family social housings, aiming to rethink spaces, focusing on some elements necessary to protect the health and well-being of the inhabitants. The method applied concepts of functionality and useful area, in addition to the requirements and criteria of the Brazilian bioclimatic zoning and performance standards, including the construction guidelines for single-family social housings (SH) reflecting on the need to adapt SH to guarantee well-being and inhabitants' health. Analysis results showed that low-income buildings are precarious in terms of functionality and do not allow adaptations due to the architectural design and technical specification of walls and window frames.
\end{abstract}

Keywords: Functionality; Natural ventilation; Social housing; Pandemic.

\section{Resumo}

No contexto da pandemia COVID-19, espaços inadequados em termos de dimensões dos ambientes e falta de flexibilidade para possíveis ajustamentos, não só acentuam os riscos para a saúde, mas também interferem na produtividade do trabalho à distância e no desempenho escolar. Neste sentido, as habitações sociais têm um desempenho insatisfatório em termos de funcionalidade, principalmente porque têm espaços pequenos e caixilhos de janelas inadequados para conseguir uma ventilação natural satisfatória e reduzir o contágio por coronavírus. O objetivo deste artigo é analisar três habitações sociais unifamiliares, visando repensar espaços, concentrando-se em alguns elementos necessários para proteger a saúde e o bem-estar dos habitantes. O método aplicou conceitos de funcionalidade e área útil, para além dos requisitos e critérios do zoneamento bioclimático brasileiro e das normas de desempenho, incluindo as diretrizes de construção de habitações sociais unifamiliares ( $\mathrm{SH}$ ) refletindo sobre a necessidade de adaptar as SH para garantir o bem-estar e a saúde dos habitantes. Os resultados da análise mostraram que os edifícios de baixo rendimento são precários em termos de funcionalidade e não permitem adaptações devido à concepção arquitetônica e especificação técnica de paredes e caixilhos de janelas.

Palavras-chave: Funcionalidade; Ventilação natural; Habitação social; Pandemia.

\section{Resumen}

En el contexto de la pandemia de COVID-19, los espacios inadecuados en cuanto a las dimensiones de las habitaciones y la falta de flexibilidad para posibles ajustes no sólo acentúan los riesgos para la salud, sino que también interfieren en la productividad del trabajo a distancia y el rendimiento escolar. En este sentido, las viviendas sociales obtienen un mal resultado en términos de funcionalidad, principalmente porque tienen espacios pequeños y marcos de ventanas inadecuados para lograr una ventilación natural satisfactoria y reducir el contagio de coronavirus. El objetivo de este artículo es analizar tres viviendas sociales unifamiliares, con el fin de repensar los espacios, centrándose en 
algunos elementos necesarios para proteger la salud y el bienestar de los habitantes. El método aplicó los conceptos de funcionalidad y superficie, además de los requisitos y criterios de la zonificación bioclimática brasileña y las normas de rendimiento, incluidas las directrices de construcción de viviendas sociales unifamiliares (SH) que reflejan la necesidad de adaptar las SH para garantizar el bienestar y la salud de los habitantes. Los resultados del análisis mostraron que los edificios de bajo rendimiento son precarios en términos de funcionalidad y no permiten adaptaciones debido al diseño arquitectónico y la especificación técnica de los muros y los marcos de las ventanas.

Palabras clave: Funcionalidad; Ventilación natural; Vivienda social; Pandemia.

\section{Introduction}

COVID-19 transformed our built environment because of fear of infection, so architecture and urbanism after the Covid-19 epidemic will never be the same. Thus, the importance of designing a healthy and sustainable built environment is highlighted (MEGAHED \& GHONEIM, 2020). In this sense, Social housing (SH) is characterized by the poor quality of housing production, as well as the peripheral location of the developments, allied to this contextualization, the unsatisfactory performance of functionality of these buildings is cited, in addition to architectural projects elaborated in a more economical approach than technical.

In addition to social housing problems, there are sanitary and environmental problems, which leads to the spread of endemic diseases and currently the coronavirus pandemic. The new coronavirus agent was discovered on 12/31/19 after cases registered in China. This agent causes the disease called coronavirus (COVID-19). Coronavirus is a family of viruses that cause respiratory infections.

Therefore, in this time of the COVID-19 pandemic, health issues are a matter of concern, to reduce contagion between family members and neighbors, in addition to ensuring some comfort and functionality in the homes in order to maintain physical and mental health due to the necessary confinement. Ensuring flexible and adaptable spaces for all users can make housing more sustainable, able to adapt to changing needs and to changing lifestyles (MEGAHED \& GHONEIM, 2020).

The configuration of the internal environments built inside a building has a main role to play before (prevention), during (containment and mitigation) and afterwards (contingency planning and planning of measures to compensate for future risks) epidemics (KAMPF et al., 2020).

But how SH could be rethought is the question of this work. In this sense, one of the requirements and criteria of NBR 15575 (ABNT, 2013) addresses performance regarding ventilation (open window). The targets of ventilation are salubrity (hygienic ventilation) and thermal comfort (removal of thermal load). This regulation also deals with the functionality of buildings when it recommends in Annex G, the minimum furniture and circulation between the furniture through the rooms.

The NBR 15575 (ABNT, 2013) is applicable to residential buildings with up to five floors, considering systems designed, built, operated and submitted to maintenance interventions that attend the specific instructions of the respective operation, use and maintenance manual.

On the other hand, the NBR 15220-3 (ABNT, 2005), establishes a Brazilian bioclimatic zoning covering a set of recommendations and constructive strategies for single-family social housing. Based on these regulations and establishing the concept of functionality, using the methodology of Boueiro Filho (2008) on ergonomic indices, the main objective of this article is the analysis of three single-family social housings built in a bioclimatic Zone 8 in the North of Brazil, aiming to give a practical reflection to rethink spaces, focusing on some elements necessary to protect the health and inner well-being of the inhabitants.

\section{Theoretical Reference}

The World Health Organization (WHO, 1995) defines that health is composed of physical well-being (proper functioning of our bodies and the ability to resist disease), mental (absence of mental illness, as well as contentment and peace) and social (individual sense of belonging and social engagement). 
People spend most of their time ( 90\%) indoors (MONTES, 2018) and buildings are becoming essential to boost the health of the population.

The term "healthy building", recently adopted by researchers, is defined as a built structure that promotes the positive well-being of individuals (LIMA et al., 2019). However, engineers, architects and designers do not have a systematic process to incorporate the fundamentals of health offered by WHO, in buildings and environments. Ten issues must be addressed to conceptualize health in buildings (AWAD et al., 2020):

1) How do buildings affect the health of occupants?

2) Question 2: How is occupant health in buildings assessed?

3) Question 3: To what extent is occupant health considered as an objective?

4) Question 4: What is the relationship between occupant-centric and performance-based metrics?

5) Question 5: How does socioeconomic status impact occupant health in buildings?

6) Question 6: What are the economic impacts of unhealthy buildings?

7) Question 7: How do extreme events affect health in buildings?

8) Question 8: What has the COVID-19 pandemic taught us about health in buildings?

9) Question 9: How can emerging technologies help achieving healthy buildings?

10) Question 10: What are the future research directions for healthy buildings?

Questions 1 to 4 provide an overview of healthy buildings, their effects on occupant health and performance; 5 and 6 focus on the social and economic impacts of unhealthy buildings; 7 and 8 investigate new stressors that affect the health of occupants in buildings; and 9 and 10 examine what technologies can offer in this field.

As for the environmental assessment, Bentayeb et al. (2015), show the importance of ventilation in preventing the adverse effects of air pollution. The results showed that only $19 \%$ of individuals had an adequate ventilation system in the nursing home for the elderly, where this population had high levels of $\mathrm{CO}_{2}$ exposure that were significantly associated with constant shortness of breath and cough, in addition to showing a significant relationship between exposure to indoor air chemical pollutants and the respiratory damage caused to the elderly.

These researchers concluded that the presence of inadequate ventilation showed more pronounced effects of some air pollutants on the impairment of respiratory health in poorly ventilated elderly homes compared to nursing homes with adequate ventilation. These adverse effects were greater in the case of insufficient ventilation and in those individuals over the age of 80 years.

The fundamental right to house was instituted by the Brazilian Federal Constitution of 1988, and from that date to the present days, the study and analysis of the housing issue is justified within the scope of the fundamental defense of individual and collective human rights.

As for the SH nomenclature, it came up with the National Housing Policy by the regulation of Law $\mathrm{n}^{\circ} 11.124 / 2005$ (BRAZIL, 2005), which dispose for the National Social Housing System. However, previously other popular housing programs have existed since the extinction of National Housing Bank in 1986. Thus, in several institutionalized phases in governmental administrations at the federal level, decentralized programs, plans and actions, the problem continues to grow and the violation of human rights is constant (LIMA et al., 2019).

However, the demand for housing is growing and in this moment of pandemic, the prospects for an increase in the search for housing that serve public health is greater. The outbreak of COVID-19 was declared a pandemic by the World Health Organization (WHO) on March 11th, 2020. 
According to the World Health Organization (WHO), the majority of patients with COVID-19, about $80 \%$ arem asymptomatic and $20 \%$ may require hospital care because they have difficulty breathing and in these cases approximately $5 \%$ may need support for the treatment of respiratory failure (ventilatory support). Thus, it is requested that the population is confined in their homes so as not to overburden the health system.

COVID-19 is currently classified as Biological Risk 3 according to Ordinance n. 2,349 GM/MS, of September 14th, 2017, of the Health Biosafety Commission, of the Ministry of Health for presenting capacity for transmission through the respiratory and that cause human or animal pathologies, potentially lethal, because there are usually treatment and/or prevention measures and represent a risk if disseminated in the community and in the environment, and can spread from person to person.

Transmission occurs from one sick person to another or through close contact by touching via a handshake; droplets of saliva; sneeze; coughing or contaminated objects or surfaces (such as cell phones, tables, door handles, toys, computer keyboards, etc).

The COVID-19 virus can be transmitted from person to person, directly or indirectly. Direct transmission occurs when there is contact with the infected person's secretions through the drops produced by coughing, sneezing and talking. Drops of saliva can travel 2 meters. Indirect transmission occurs through contact with a contaminated surface. Depending on how virulent the virus is, it can be transmitted by touching something an infected person has touched and then touching the mouth, nose or eyes.

KAMPF et al. (2020) point out that the new coronavirus can survive for about 72 hours on surfaces. The residence times of the virus on the surface differ in the different types of materials on the surfaces. In papers and cardboard the time is 4 to 5 days, in plastic 5 days, in steel 48 hours, in aluminum 2 to 8 hours, surgical gloves 8 hours, on glass and wood 4 days (KAMPF et al., 2020). In this context, it is necessary to invest in the ventilation of all housing places, especially in rooms with people at risk, in addition to being essential for preventing the spread of viruses and bacteria and guaranteeing human health conditions and promoting thermal comfort of the occupants inside the building. Thus, natural ventilation helps prevent viral diseases, such as coronavirus and H1N1 flu.

Natural ventilation also contributes to the reduction of energy costs, since it does not require artificial systems, such as air conditioning, which often become means of transporting microorganisms. Therefore, natural ventilation becomes essential to generate more comfortable and healthy places.

In this sense, Sobreira (2015) comments that contamination with microorganisms can affect the well-being and health of humans. The author comments on the buildings that have a negative influence on the health and well-being of the occupants that are called "Sick Buildings". The main characteristics associated with this type of buildings are the lack of fresh air renovation and deficient ventilation systems.

It is noteworthy that the spatial composition of the environments can be a good ally in combating and preventing the new coronavirus, however many of the projects developed for $\mathrm{SH}$ disregard the importance of natural ventilation and end up repeating patterns from north to south of the country due to typologies and materials. Bioclimatic architecture is the design process that reduces energy consumption and environmental impacts through naturally available resources.

It is easy to understand that the "individual isolation" of people in their spaces, to avoid viral contagion via air or by contact on surfaces is particularly difficult in small space dwellings, inhabited by many people, including children, the elderly and the most fragile.

Thus, the importance of adapting the HIS to the need for an ideal air exchange is emphasized in order to reduce the half-life of the coronavirus in the environment. 
The need for people's confinement caused by the pandemic has been detrimental to the physical and mental health of the population, weighing particularly on the most vulnerable, since contributed to the worsening of chronic diseases (cardiovascular diseases and diabetes) and mental problems such as anxiety, insomnia, depression and learning problems in children (D'ALESSANDRO et al., 2020). The authors also comment on the problems of ergonomics and accessibility found in housings during these pandemic moments and mention that the overcrowding of a house does not depend only on the number of people who share it, but is also conditioned by the age, relationship and sex of the inhabitants.

Therefore, it is necessary to adopt targeted strategies and design solutions suitable for living spaces, paying special attention to the size of the environments, to ensure health, accessibility and internal flexibility, in order to allow adaptability to any changes in the distribution of the structure, both in the short term as for the long term, these criteria are very difficult with regard to the architectural projects of the $\mathrm{SH}$.

The quality of the housing and its surroundings have their own characteristics and must incorporate the possibility of long-term adaptation, in addition to sociocultural adaptation, allowing the compatibility of the diverse needs of each resident within a single house (LAPETINA, 2007). According to WHO, the living space should be to ensure adequate privacy in order to meet the needs of occupants, be accessible and usable for extended users and large enough to comfortably accommodate people of different ages. Therefore, it must meet ergonomic requirements, to safeguard the safety of users, without requiring special protection measures and must meet the need for privacy and characteristics that allow it to be used to perform daily activities in total safety and well-being (D'ALESSANDRO et al., 2020). The housings units must meet different needs over time, also in light of the current situation linked to COVID-19.

Boueri Filho (2008) presents a methodology that encompasses five criteria in the analysis of ergonomics, however functionality can be applied according to the needs of the inhabitants. For each of these criteria, the environments are classified as good, satisfactory, regular and precarious: useful area of the housing that corresponds to the dimensional capacity of the housing to support, in all environments, the execution of domestic tasks in appropriate, efficient and safe ways; useful area of the environment represents the dimensional capacity of the environment to support the performance of domestic tasks in an appropriate, efficient and safe manner; composition of furniture and equipment that refers to the capacity of the environment to receive furniture and or equipment necessary for the performance of domestic activities, being able to support an increase or an innovation of activities within this space; door and window connections indicate how the location of the door and window allows the environment to support flexibility in the arrangement of furniture and equipment without impairing circulation, access and the execution of domestic tasks in an appropriate, efficient and safe way; housing typology and family cycle represents how the housing typology supports the family composition during the complete family cycle.

The NBR 15220-3 (ABNT, 2005) aims at the climatic adaptation of single-family social housings, with up to three floors, establishes the Brazilian bioclimatic zoning by subdividing Brazil into eight bioclimatic zones and has no normative character, only for guidance.

The referred standard considers parameters and boundary conditions and establishes for the formulation of the construction guidelines for each Brazilian bioclimatic zone and for the establishment of passive thermal conditioning strategies: size of ventilation openings; protection of openings; external seals (type of external wall and type of cover); and passive thermal conditioning strategies.

In this study, the housings are directed to the Bioclimatic Zone 8, considering the data according to Table 1. 
Table 1 - Parameters and boundary conditions - Bioclimatic zone 8.

\begin{tabular}{c|c}
\hline $\begin{array}{c}\text { Ventilation } \\
\text { openings }\end{array}$ & $\begin{array}{c}\text { Big - A (\% of floor area) }>40 \% \\
\text { The effective openings for ventilation are given as a percentage of the floor area } \\
\text { in long-stay environments (kitchen, bedroom, living room) }\end{array}$ \\
\hline $\begin{array}{c}\text { Shading of } \\
\text { openings }\end{array}$ & Shade openings \\
\hline $\begin{array}{c}\text { Passive thermal } \\
\text { conditioning } \\
\text { strategies - } \\
\text { Summer }\end{array}$ & Permanent cross-ventilation \\
\hline $\begin{array}{c}\text { Thermal } \\
\text { conditioning } \\
\text { strategies }\end{array}$ & $\begin{array}{c}\text { I/J - Cross-ventilation is achieved by circulating air through the building } \\
\text { environments. This means that if the environment has windows on only one } \\
\text { facade, the door should be kept open to allow for cross-ventilation. Attention } \\
\text { should also be paid to the prevailing winds in the region and to the surroundings, } \\
\text { as the surroundings can significantly change the direction of the winds. }\end{array}$ \\
\hline
\end{tabular}

Source: Adapted from NBR 15220-3 (2005).

NBR 15575-4 (ABNT, 2013), on the other hand, has as a requirement with regard to ventilation openings (Table 2), present openings on the façades of the housings, with adequate dimensions to provide the internal ventilation of the environments applied only to long-stay environments: rooms and bedrooms. When the criteria are not defined in specific legislation at the construction site, including construction codes, sanitary codes and others, the values indicated in Table 2 adapted from the mentioned norm for the bioclimatic zone 8 must be adopted.

Table 2 - Minimum ventilation area in rooms and bedrooms.

\begin{tabular}{l|l}
\hline \multirow{2}{*}{ Performance level } & Ventilation opening (A) \\
\cline { 2 - 2 } & Zone 8 - big openings \\
\hline Minimum & $\mathrm{A} \geq 12 \%$ of floor area - north region of Brazil \\
\hline
\end{tabular}

Source: Adapted from NBR 15575-4 (2013).

The evaluation method takes place through the analysis of the architectural project, considering, for each long-stay environment, the following relationship:

$$
\mathrm{A}(\%)=100 *\left(\frac{A A}{A P}\right)
$$

Where: AA - it is the effective area of ventilation of the environment, and for the calculation of this area only the openings that allow free air circulation are considered, and the areas of profiles, glass and any other obstacle must be discounted; internal door areas are not counted in this area. In case of rooms with balcony doors or similar, on the building facade, the entire open area resulting from the displacement of the movable door leaf is computed. And, AP - is the floor area of the environment.

Also, the Brazilian performance standard NBR 15575-1 (ABNT, 2013) states that the user's requirements regarding habitability are expressed by the following factors: health, hygiene and air quality. Natural ventilation is the renewal of indoor air by fresh outdoor air, using only openings in the surroundings with an adequate area, manually regulated or self-controlled through natural mechanisms of wind and air movement due to temperature differences. This renewal through the introduction of clean air and extraction of stale air should preferably occur in a controlled manner, through ventilation flows (RSECE, 2006). Ventilation is essential for the health and comfort of occupants in any type of housing, in addition to being necessary to reduce and remove all pollutants emitted by many sources existing in the interior environment. 
Among the processes for applying natural ventilation, strategies are the so-called chimney effect and cross-ventilation. The chimney effect occurs from openings in the lowest and highest part of the house, as the hot, less dense air is repelled by the cold air due to pressure differences, promoting a milder and more ventilated environment.

Cross-ventilation, on the other hand, occurs when there are at least two openings (doors or windows) on the sides of opposite or adjacent walls, preferably those with the dominant wind direction, allowing for cross wind flow and air renewal. The opening windows in general, allow $100 \%$ of their ventilation area, while the sliding windows this index is about $50 \%$, since part of the opening is sealed by the window itself.

Even with an open window or door, natural ventilation can be limited if the indoor and outdoor temperatures are similar and there is little wind. According to the United States Environmental Protection Agency (EPA, 2020) to increase natural ventilation: open more than one window or door, if possible; do not open windows and doors if this poses a safety or health risk to children or other family members (risk of falling or triggering asthma symptoms); ventilation can be increased even more through cross-ventilation, opening windows (or doors) on opposite sides of a house (but preferably not directly opposite each other) and keeping the internal doors open; opening the highest and lowest windows in a house at the same time (especially on different floors) can also help to increase ventilation; for double windows (the most common type), opening the top strip of one window and the bottom strip of another window also encourages ventilation. Even when using a single window, partially opening the top and bottom strips can help improve ventilation.

With regard to the intake of air, two types of openings are provided for this to occur. One in a facade wall (which includes the openings of the frames and other elements of the facades) and the ducts, which can be individual or collective. The layout of the compartments and the orientation of the openings to the outside should preferably be coordinated with the prevailing wind direction in order to favor the intake of outside air by the main compartments.

It is noted that, generally, the frames used in housings are of the sliding type, which is associated with economic issues, but this opening mode partially prevents cross-ventilation. It is known that air quality in confined spaces plays a direct or indirect role in preventing health. Based on the question of internal air conditioning systems, especially during the summer and the possibility of increasing the risk of COVID-19 transmission among occupants, it is preferable to suspend mechanical systems, ensuring natural ventilation through the more frequent opening of the window, especially if some rooms have been adapted as remote work and homework stations (D’ALESSANDRO et al., 2020).

\section{Methodology}

The methodology was carried out through bibliographic research in articles, dissertations, theses and academic papers that deal with functionality, ergonomics, natural ventilation and quality of housing projects. Thus, it was decided to use the Boueri housing ergonomic indices method, in addition to the technical standards NBR 15220-3 (ABNT, 2005) and NBR 15575-4 (ABNT, 2013) for the analysis of the adequacy regarding natural ventilation according to the dimensions of the structures used in social housing built in bioclimatic zone 8 in northern Brazil, according to Tables 3 and 4 . A survey was carried out of the requirements to be met in the private areas of the buildings presented below, Figures 1, 2 and 3.

Type A - Multifamily - area $41.39 \mathrm{~m}^{2}$ - Construction System: Structural masonry of hallow concrete blocks.

Type B - Single-family semi-detached - area $40.80 \mathrm{~m}^{2}$ - Construction System: Masonry without structural function of bricks and ceramic blocks.

Type C - Single-family semi-detached - area $41.74 \mathrm{~m}^{2}$ Construction System: Reinforced concrete structural walls.

The floor areas: Living room (LV); Couple's bedroom (CB); Single bedroom (SB); Kitchen (K); Bathroom (B). 
Table 3 - Area of floor and frames.

\begin{tabular}{|c|c|c|c|c|c|}
\hline \multicolumn{3}{|c|}{ Floor area $\left(\mathbf{m}^{2}\right)$} & \multicolumn{3}{|c|}{ Area window frames $\left(\mathrm{m}^{2}\right)$} \\
\hline $\mathrm{CB}$ & SB & LR & $\mathrm{CB}$ & SB & LR \\
\hline 9.24 & 7.00 & 9.09 & 1.44 & 1.44 & 1.44 \\
\hline \multicolumn{3}{|c|}{ Type of frames } & \multicolumn{3}{|c|}{ Sliding iron window with fixed flag folded plate fancy glass $4 \mathrm{~mm}$} \\
\hline 7.53 & 7.23 & 10.78 & 1.21 & 1.21 & 1.21 \\
\hline \multicolumn{3}{|c|}{ Type of frames } & \multicolumn{3}{|c|}{ Sliding iron window with fixed flag folded plate fancy glass $4 \mathrm{~mm}$} \\
\hline 8.97 & 8.28 & 10.08 & 1.44 & 1.44 & 1.44 \\
\hline \multicolumn{3}{|c|}{ Type of frames } & \multicolumn{3}{|c|}{ Sliding iron window with fixed flag folded plate flat glass $6 \mathrm{~mm}$} \\
\hline
\end{tabular}

Source: Authors (2021).

The criteria according to Boueri Filho (2008) are:

- Good: 16 a 14 Useful area of $\mathrm{SH} \mathrm{m}$ /hab. - It supports great flexibility in the arrangement of basic furniture and equipment. The housing typology adequately supports the entire family cycle;

- Satisfactory: 14 a 12 Useful area of $\mathrm{SH} \mathrm{m}$ /hab. - The environment supports the usual furniture and basic equipment. It supports few flexibilities in the arrangement of basic furniture and equipment. The housing typology adequately supports the $2 / 3$ of family cycle;

- Regular: 12 a 10 Useful area of $\mathrm{SH} \mathrm{m}$ /hab. - The environment supports the usual furniture and basic equipment. The environment supports basic furniture and equipment with reduced dimensions to the usual ones. It does not support flexibility in the arrangement of basic furniture and equipment. The housing typology adequately supports the $1 / 2$ of family cycle;

- Precarious: 10 a 8 Useful area of $\mathrm{SH} \mathrm{m}$ /hab. - The environment does not support the usual furniture and basic equipment. The connection creates conflicts in the arrangement and use of basic furniture and equipment. The housing typology adequately supports the $1 / 3$ of family cycle.

Table 4 - Useful area of environments - ergonomic index of Boueri’s housing.

\begin{tabular}{c|c|c|c|c|c}
\hline \multirow{2}{*}{ Classification } & \multicolumn{6}{|c}{ Useful area of environments $\left(\mathbf{m}^{2}\right)$} \\
\cline { 2 - 6 } & LV & CB & SB & K & B \\
\hline \multirow{4}{*}{ Good } & 18 & 18 & 15 & 12 & 6 \\
& $\vdash$ & $\vdash 15$ & $\vdash$ & $\vdash$ & $\vdash$ \\
& 15 & & 12 & 10 & 5.5 \\
\hline \multirow{4}{*}{ Satisfactory } & 15 & 15 & 12 & 10 & 5.5 \\
& $\vdash$ & $\vdash$ & $\vdash$ & $\vdash$ & $\vdash$ \\
& 12 & 12 & 10 & 8 & 5 \\
\hline \multirow{3}{*}{ Pregular } & 12 & 12 & 10 & 8 & 5 \\
& $\vdash$ & $\vdash$ & $\vdash$ & $\vdash$ & $\vdash$ \\
& 9 & 9 & 8 & 6 & 4.5 \\
\hline & 9 & 9 & 8 & 6 & 4.5 \\
& $\vdash$ & $\vdash$ & $\vdash$ & $\vdash$ & $\vdash$ \\
& 6 & 6 & 6 & 4 & 4 \\
\hline
\end{tabular}

Source: Authors (2021). 


\section{Results and Discussion}

The results will be discussed according to the SH parameter and typology. According to the criteria of Boueri Filho (2008) regarding the useful area of housing, all buildings are considered regular (Table 5).

Table 5 - Evaluation according to the criterion of useful area of the housing.

\begin{tabular}{c|c|c|c|c}
\hline SH & Total usefull area $\left(\mathbf{m}^{\mathbf{2}}\right)$ & Inhabitat (unity) & Useful area/ inhabitant & Criterion \\
\hline A & 41.39 & 4 & 10.35 & Regular \\
\hline B & 40.80 & 4 & 10.2 & Regular \\
\hline C & 41.74 & 4 & 10.44 & Regular \\
\hline
\end{tabular}

Source: Authors (2021)

Regarding the criterion for assessing the useful area by environment, it was observed that the kitchen and bathroom areas were classified as precarious for all $\mathrm{SH}$, the bedrooms were considered to be regular to precarious and the rooms to be satisfactory to regular (Table 6).

Table 6 - Evaluation of the useful area of the environment.

\begin{tabular}{c|c|c|c|c|c}
\hline Classification & LV & CB & SB & K & B \\
\hline Satisfactory & SH A & - & - & - & - \\
\hline Regular & SH B e C & SH A e C & SH C & - & - \\
\hline Precarious & - & SH B & SH A e B & SH A, B e C & SH A, B, e C \\
\hline \multicolumn{7}{c}{ Source: Authors (2021). }
\end{tabular}

Regarding the composition of furniture and equipment, all SH were considered in the classifications from regular to precarious, as they do not allow flexibility. With regards to SH E, in which the walls are executed with reinforced concrete of $10 \mathrm{~cm}$, the foundation in radier and slab executed in reinforced concrete covered with asbestos tile, this criterion becomes very relevant, as well as SH type A because they are building blocks in structural masonry.

Regarding the criterion related to door and window connections, SH were classified as regular to precarious. As for the access and execution of domestic tasks due to the reduced dimensions of the SH environments, they are significantly impaired.

As for the type of housing and family cycle are considered regular, the housing adequately supports $1 / 2$ of the entire family cycle. Tables 7 and 8 refer to the requirements for ventilation openings that were unsatisfactory according to the criteria of the technical standards.

Table 7 - Requirement - ventilation openings NBR 15575-4.

\begin{tabular}{c|c|c|c|c}
\hline \multirow{2}{*}{ SH } & \multicolumn{3}{|c|}{$\begin{array}{c}\text { A } \\
(\%)\end{array}$} & $\begin{array}{c}\text { Criterion } \\
\text { A } \geq \mathbf{1 2 \%} \text { of floor area }\end{array}$ \\
\cline { 2 - 5 } & CB & SB & LR & \\
\hline A & 7.79 & 10.29 & 7.92 & unsatisfactory \\
\hline B & 8.03 & 8.37 & 5.61 & unsatisfactory \\
\hline C & 8.03 & 8.70 & 7.14 & unsatisfactory \\
\hline
\end{tabular}

Source: Authors (2021). 
Table 8 - Requirement - ventilation openings NBR 15220-3.

\begin{tabular}{c|c|c|c|c}
\hline \multirow{2}{*}{ SH } & \multicolumn{3}{|c|}{ A } & \multirow{2}{*}{$\begin{array}{c}\text { Criterion } \\
\text { 40\% }\end{array}$} \\
\cline { 2 - 4 } & CB & SB & LR & \\
\hline A & 7.79 & 10.29 & 7.92 & unsatisfactory \\
\hline B & 8.03 & 8.37 & 5.61 & unsatisfactory \\
\hline C & 8.03 & 8.70 & 7.14 & unsatisfactory \\
\hline
\end{tabular}

Source: Authors (2021).

Table 9 deals with the requirements and criteria established in NBR 15220-3 (ABNT, 2005) that aim at the climatic adaptation of single-family social housing. The SH analyzed do not include opening shading strategies or elements. As for cross-ventilation, these are partially used, since the frames used are sliding (Table 9). Another problem that SH present when it comes to cross-ventilation is when it is obtained through the circulation of air through the building environments due to the type of opening window and due to obstacles (for example, walls) that do not allow circulation of the air continuously, which becomes more affected in the summer period.

Table 9 - Criteria.

\begin{tabular}{c|c|c|c|c}
\hline Requirements & Criteria & A & B & C \\
\hline Shading of openings & Shade openings & No & No & No \\
\hline $\begin{array}{c}\text { Passive thermal conditioning } \\
\text { strategies - summer }\end{array}$ & Permanent cross-ventilation & Partial & Partial & No \\
\hline $\begin{array}{c}\text { Thermal conditioning } \\
\text { strategies }\end{array}$ & $\begin{array}{c}\text { I/J - A cross-ventilation is achieved by circulating } \\
\text { air through the building environments }\end{array}$ & Partial & Partial & No \\
\hline
\end{tabular}

Source: Authors (2021).

In order for cross-ventilation to occur, the frames of the facades must allow air to circulate, it is observed that $\mathrm{SH} A$ (Figure 1) does not meet cross-ventilation, as the windows were not arranged in the opposite direction to each other and thus, it would be it is necessary to keep the doors of the rooms always open or to insert flags to allow air to circulate, in addition the window of the room was arranged in a recessed facade, which causes a loss of wind force.

Figure 1. SH A.

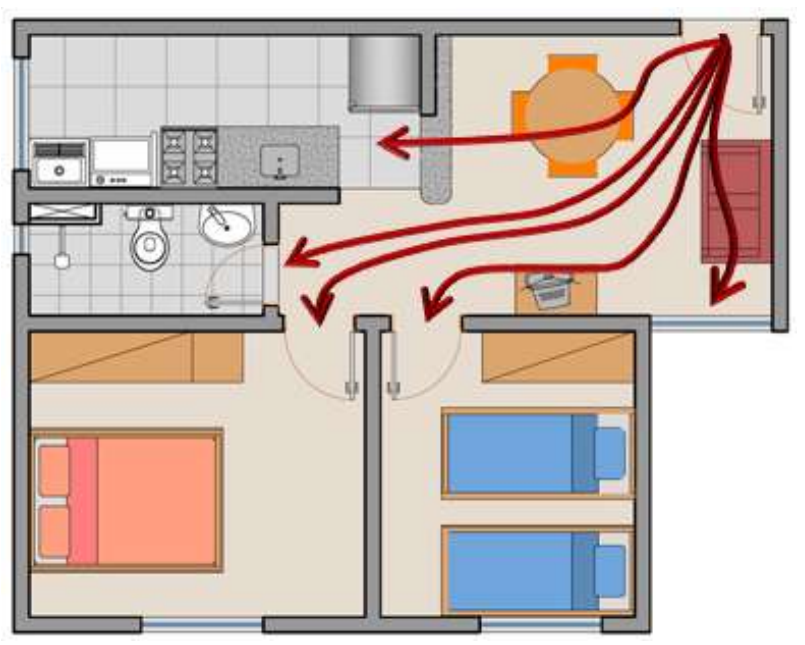

Source: Adapted from PMCMV (2007). 
In the case of SH B (Figure 2) it partially meets the cross-ventilation because the arrangement of the living room and kitchen frames allows circulation and air exchange, however the rooms were impaired in this criterion, since the frames encounter obstacles to air propagation permission.

Figure 2. SH B.

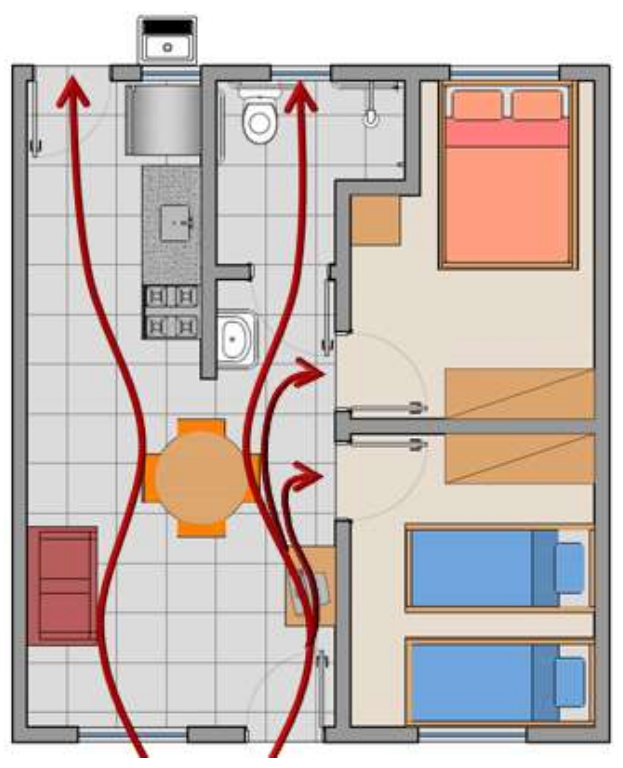

Source: Adapted from PMCMV (2007).

The arrangement of SH C (Figure 3) frames impairs cros-ventilation and air circulation between environments. The only way to enable cross-ventilation would be to leave the bedroom doors open, which restricts the privacy of individuals.

Figure 3. $\mathrm{SH} \mathrm{C}$

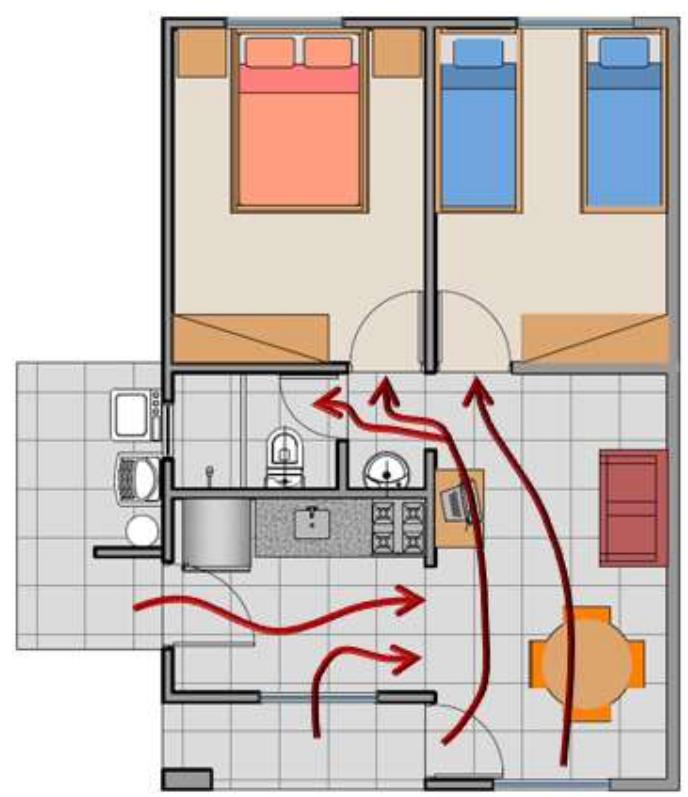

Source: Adapted from PMCMV (2007). 


\section{Conclusions}

It is considered that the criteria adopted in SH architectural projects should favor the choice of complementary activities and compatible with the health and well-being of the occupants, defining layouts in order to minimize the negative impacts that the presence of different activities can generate, in addition to agents such as the coronavirus.

The housings units and living spaces, even if small, when located in densely built areas, must be designed according to at least the basic hygiene principles of the building.

The space available at SH is insufficient or inadequate to carry out the basic activities of daily life. The frames used in the projects do not meet the criteria of cross-ventilation, both due to the type of opening and the layout on the facades. For this bioclimatic zone, it would be necessary to include flags on the doors, as it is a hot and humid region with low ventilation all year round.

In addition, the technical specifications adopted for the walls exclude the possibility of long-term adjustments and necessary extensions that guarantee the family cycle and pandemic situations. People need houses that can effectively provide social isolation and offer protection from viruses and infections. The expectation is that even after the quarantine period, more people will work from home.

\section{References}

Awada, M., Becerik-Gerber, B., Hoque, S., O'neill, Z., Pedrielli, G., Wen, J. \& Wu, T. (2020). Ten questions concerning occupant health in buildings during normal operations and extreme events including the COVID-19 pandemic. Building and Environment, 188, 1-11.

Bentayeb, M., Norback, D., Bednarek, M., Bernard, A., Cai, G., Cerrai, S., Eleftheriou, K. K., Gratziou, C., Holst, G. J., Lavaud, F.; Nasilowski, J., Sestini, P., Sarno, G., Sigsgaard, T., Wieslander, G., Zielisnki, J., Viegi, G. \& Annesi-maesano, I. (2015). Indoor air quality, ventilation and respiratory health in elderly residents living in nursing homes in Europe. European Respiratory Journal, 45, 1228-1238.

Boueri Filho, J. J. (2008). Projeto e Dimensionamento dos Espaços da Habitação Espaço de Atividades. São Paulo: Estação das Letras e Cores.

BRAZIL. (2017). Ordinance No. 2,349, of September 14, 2017. Risk Classification of Biological Agents prepared in 2017, by the Health Biosafety Commission (CBS), of the Ministry of Health. Available at: http: // bvsms. saude.gov.br/bvs/saudelegis/gm/2017/prt2349_22_09_2017.html.

BRAZIL. (2005). Law No. 11,124, of June 16, 2005. Provides for the National Housing System of Social Interest - SNHIS, creates the National Housing Fund of Social Interest - FNHIS and establishes the FNHIS Management Council. Official Gazette of the Federative Republic of Brazil, Executive Branch, Brasília, DF, June $17,1,1$.

Brazilian association of technical standards. (2005). NBR 15220-3: Thermal performance of buildings - Part 3: Brazilian bioclimatic zoning and construction guidelines for single-family homes of social interest. Rio de Janeiro.

Brazilian association of technical standards. (2013). NBR 15575-1: Residential Buildings - Performance. General requirements. Rio de Janeiro.

Brazilian association of technical standards. (2013). NBR 15575-4: Residential buildings - Performance - Part 4: Requirements for internal and external vertical fencing systems - SVVIE. Rio de Janeiro.

D’alessandro, D., Gola, M., Appolloni, L., Dettori, M., Fara, G. M., Rebecchi, A., Settimo, G. \& Capolongo, S. (2020). COVID-19 and Living Spaces challenge. Well-being and Public Health recommendations for a healthy, safe, and sustainable housing. Acta Biomed, 91,61 - 75.

Ho, D. C. W., Leung, H. F., Wong, S. K., Cheung, A. K. C., Lau, S. S. Y., Wong, W. S., Lung, D. P. Y. \& Chau, K. W. (2004). Assessing the health and hygiene performance of apartment buildings. Facilities, 22, $58-69$.

Kampf, G., Todt, D., Pfaender, S. \& Steinmann, E. (2020). Persistence of coronaviruses on inanimate surfaces and their inactivation with biocidal agents. The Journal of Hospital Infection, 104, 246-251.

Klepeis, N. E. Nelson, W. C., Ott, W. R., Robinson, J. P., Tsang, A. M., Switzer, P., Behar, J. V., Hern, S. C. \& Engelmann, W. H. (2001). The National Human Activity Pattern Survey (NHAPS): a resource for assessing exposure to environmental pollutants. Journal of Exposure Analysis and Environmental Epidemiology, 11, 231-252.

Lai, K. Y., Webster, C., Kumari, S. \& Sarkar, C. (2020). The nature of cities and the Covid-19 pandemic. Current Opinion in Environmental Sustainability, 46, 27-31.

Lapetina, C. M. L. (2007). Uma contribuição para a avaliação da qualidade no dimensionamento dos espaços da habitação. Master's Dissertation, Universidade de São Paulo.

Lima, A. C., Galvan, G. \& Roesler, M. R. V. B. (2019). O direito humano à moradia digna e à inclusão social no centro da agenda urbana e da política habitacional. In: Congresso Brasileiro de Assistentes Sociais, 16, 1, 1 - 12.

Megahed, N. A. \& Ghoneim, E. M. (2020). Antivirus-built environment: lessons learned from covid-19 pandemic. Sustainable Cities and Society, 61, 102350. 
Research, Society and Development, v. 10, n. 12, e45101220114, 2021

(CC BY 4.0) | ISSN 2525-3409 | DOI: http://dx.doi.org/10.33448/rsd-v10i12.20114

Montes, M. A. T. (2018). Mudança de paradigmas nos projetos de habitação de interesse social: arquitetura resiliente e avaliação no ciclo de vida. Revista Ímpeto, 8, 53 - 59 .

Portuguesa, N. NP 1037-1. (2002). Ventilation and Evacuation of Combustion Products from Locations with Gas Appliances, Part 1: Residential Buildings. Natural ventilation. Portugal.

RSECE. (2006). Regulation of Energy Conditioning Systems in Buildings (RSECE). Diário da República - I Series-A, Decree-Law No. 79/2006, April 4.

Sobreira, C. D. D. B. (2015). Avaliação do desempenho da ventilação natural em lares de idosos. Master's Dissertation, Universidade Nova de Lisboa.

United states environmental protection agency. Indoor air in homes and coronavirus (COVID-19). Available at: https://www.epa.gov/coronavirus/indoor-airhomes-and-coronavirus-covid-19.

World health organization. (1995). Constitution of the World Health Organization. 